\title{
Field comparison of circulating antibody assays versus circulating antigen assays for the detection of schistosomiasis japonica in endemic areas of China
}

Yu-Chun Cai ${ }^{1,2,3 \dagger}$, Jun-Fang $\mathrm{Xu}^{4+}$, Peter Steinmann ${ }^{5,6}$, Shao-Hong Chen ${ }^{1,2,3}$, Yan-Hong Chu ${ }^{1,2,3}$, Li-Guang Tian ${ }^{1,2,3}$, Mu-Xin Chen ${ }^{1,2,3}$, Hao Li ${ }^{1,2,3}$, Yan Lu ${ }^{1,2,3}$, Ling-Ling Zhang ${ }^{1,2,3}$, Yang Zhou ${ }^{1,2,3}$ and Jia-Xu Chen ${ }^{1,2,3^{*}}$

\begin{abstract}
Background: Schistosomiasis remains a serious public health problem in affected countries, and routine, highly sensitive and cost-effective diagnostic methods are lacking. We evaluated two immunodiagnostic techniques for the detection of Schistosoma japonicum infections: circulating antibody and circulating antigen assays.

Methods: A total of 1864 individuals (between 6 and 72 years old) residing in five administrative villages in Hubei province were screened by serum examination with an indirect hemagglutination assay (IHA). The positive individuals (titer $\geq 20$ in $\mathrm{HA}$ ) were reconfirmed by stool examination with the Kato-Katz method (three slides from a single stool specimen). Samples of good serum quality and a volume above $0.5 \mathrm{ml}$ were selected for further testing with two immunodiagnostic antibody (DDIA and ELISA) and two antigen (ELISA) assays.

Results: The average antibody positive rate in the five villages was $12.7 \%$, while the average parasitological prevalence was 1.50\%; 25 of the 28 egg-positive samples were also circulating antigen-positive. Significant differences were observed between the prevalence according to the Kato-Katz method and all three immunodiagnostic antibody assays (P-value $<0.0001$ ). Similar differences were observed between the Kato-Katz method and the two immunodiagnostic antigen assays (P-value $<0.0001$ ) and between the antigen and antibody assays (P-value $<0.0001$ ).

Conclusion: Both circulating antibody and circulating antigen assays had acceptable performance characteristics. Immunodiagnostic techniques to detect circulating antigens have potential to be deployed for schistosomiasis japonica screening in the endemic areas.
\end{abstract}

Keywords: Schistosoma japonicum, Circulating antibody, Circulating antigen, China

\section{Background}

Schistosomiasis remains a serious public health problem in endemic countries [1-3], including in the People's Republic of China. According to the national annual disease report, there were 365,770 Schistosoma japonicum patients and approximately 250 million people at risk of infection in China in 2009 [4]. After a half-century fight

\footnotetext{
* Correspondence: chenjiaxu1962@163.com

${ }^{\dagger}$ Equal contributors

'National Institute of Parasitic Diseases, Chinese Center for Disease Control and Prevention, Shanghai 200025, People's Republic of China

${ }^{2}$ Key Laboratory of Parasite and Vector Biology, Ministry of Health, Shanghai 200025, People's Republic of China

Full list of author information is available at the end of the article
}

against schistosomiasis japonica, the prevalence and intensity of S. japonicum infection have decreased significantly [5-8]. Today, the prevalence is relatively low in most of the traditional endemic areas. Therefore, cost-effective routine methods for diagnosis are now required for deployment in low-endemic areas and for the correct diagnosis of infections in travelers and migrants [9-11]. Currently available diagnostic methods include direct parasitological (parasite egg detection and miracidium hatching), direct serological (circulating antigens) and indirect serological techniques (circulating antibodies). Microscopic examination of stool is traditionally considered

\section{() BioMed Central}

(c) 2014 Cai et al.; licensee BioMed Central Ltd. This is an Open Access article distributed under the terms of the Creative Commons Attribution License (http://creativecommons.org/licenses/by/2.0), which permits unrestricted use, distribution, and reproduction in any medium, provided the original work is properly credited. The Creative Commons Public Domain Dedication waiver (http://creativecommons.org/publicdomain/zero/1.0/) applies to the data made available in this article, unless otherwise stated. 
the "gold standard" for the diagnosis of schistosomiasis [12]. However, the involved procedures (mainly KatoKatz thick smears and hatching in water) are timeconsuming and have limited sensitivity due to the day-to-day fluctuations in egg output $[13,14]$. It must also be considered that for the Kato-Katz method, only $41.7 \mathrm{mg}$ of fecal material are examined per slide, limiting the chance to detect eggs in the case of light-intensity infections. This results in high rates of false-negative results in certain populations, most notably following repeated rounds of mass praziquantel administration, the current mainstay of schistosomiasis control worldwide [15-19]. It follows that the current diagnostic gold standard may be unsuitable for surveys and surveillance in communities with predominantly low-intensity infections [20-25].

Immunodiagnostic techniques may be used to detect circulating antigens of schistosomes and to detect host antibodies against the parasite. However, the immunologic diagnosis is usually not species-specific and may not reliably indicate cure in the short term $[26,27]$. Studies showed that the false-positive rates of the indirect hemagglutination test (IHA) and enzyme linked immunosorbent assays (ELISA) were very high in field settings where such tests were used to identify villagers infected with S. japonicum [28,29]. Theoretically, the false positives might be stratified into three groups: 1) infected individuals who were misdiagnosed by stool examination; 2) previously infected individuals who were cured following treatment; 3) crossreactions between antigens of/antibodies to other parasites than S. japonicum. In addition, it has been observed that immunodiagnostic assays also missed a certain number of light-intensity infections, especially in areas of relatively severe endemicity [30].

Okabe \& Tanaka [31] arguably were the first ones who described that antigens secreted by parasites and circulating in the host blood might be a potential diagnostic material [32,33]. Circulating anodic antigen (CAA) and circulating cathodic antigen (CCA) are adult worm gutassociated antigens. Serum levels of CAA are related to actual worm burden and rapidly decrease following drug treatment [34-38]. Soluble egg antigens (SEA) of $S$. japonicum represent schistosome egg metabolic and secreted antigens in a patient's blood, urine or other body fluids. Detection of SEA thus is a more direct measure of the presence of worms, providing accurate information on the status and intensity of infection. Although the schistosome species currently cannot be determined based on secreted antigens, the detection of circulating antigens (SEA, CCA and CAA) has good specificity for the diagnosis of Schistosoma spp infections, and there are very few false-positive diagnoses with these methods $[39,40]$.

\section{Methods}

\section{Ethics statement}

The study was authorized by the ethics committee of IPD, China CDC (Ref No: 20100802-1). All participants were informed about the study aims and procedures, following which they gave written informed consent to participate. Participants who were found to be parasitologically positive were given free praziquantel treatment.

\section{Study population}

A total of 1864 individuals residing in five administrative villages in Jiangling county, Hubei province participated in this study. All participants were aged between 6 and 72 years at the time of the study (August and September 2010). All participants were screened by serum examination with an indirect hemagglutination assay (IHA, LOT: 20100608 from Anji Pharmaceutical Science and Technology Co. Ltd.). Infections were confirmed by stool examination with the Kato-Katz technique for individuals with titers $\geq 20$. Each participant was asked to provide one blood sample of about $2-3 \mathrm{ml}$ collected by venipuncture, and positive individuals were asked to provide one stool sample of over $50 \mathrm{~g}$. The samples were transferred to the local schistosomiasis stations where IHA and Kato-Katz tests were performed by laboratory staff within 24 hours of sample collection. All serum samples of good quality and a volume above $0.5 \mathrm{ml}$ were selected for further testing. Immunodiagnostic antibody (DDIA and ELISA) and antigen (ELISA) assays were performed by trained staff of the National Institute of Parasitic Diseases, Chinese Center for Disease Control and Prevention (IPD, China CDC) in Shanghai after the field work.

\section{Stool examinations}

The Kato-Katz thick smear method was used to detect schistosome eggs in the collected stool samples. Three slides were prepared per sample, using a standard template holding $41.7 \mathrm{mg}$. Each slide was checked by two experienced technicians 12-48 h after their initial preparation. Eggs per gram of stool (EPG) was used to express the infection intensity, calculated as the arithmetic mean of the egg counts obtained from the three slides multiplied by 24 [41].

\section{Immunodiagnostic antibody assays - IHA, ELISA and DDIA Indirect hemagglutination assay (IHA)}

The IHA test kits were purchased form the Anhui provincial Institute of Parasitic Diseases, P.R China. The test instructions were accurately followed and all sera were tested by this method. In brief, $100 \mu \mathrm{l}$ of normal saline solution was added to the first well of the plate in the transverse line and $25 \mu \mathrm{l}$ of normal saline solution were added to the wells 2 and 3 . A total of $25 \mu$ l serum was 
then added to the first well and thoroughly mixed with the saline solution. In the next step, $25 \mu \mathrm{L}$ of the mixture in the first well was transferred to the second well and mixed as before. The same procedure was repeated for the third well. Hence, the concentration of the second well was 1:10 and that of the third well was 1:20. Positive and negative control sera were tested simultaneously on each Plate. $25 \mu \mathrm{l}$ of $2.5 \%$ sensitized red blood cells was placed into each well, shaken, and kept at $37^{\circ} \mathrm{C}$ for half an hour. The results of the test were read by eye. The terminal point of a positive reaction was the highest titer where agglutination appeared. If a positive reaction appeared at a titer 1:10, the sample was considered positive [42].

\section{ELISA antibody assay}

The ELISA test kits for detecting anti-schistosome antibodies were purchased form Shenzhen Combined Biotech Co., P.R China [43]. The experiments were operated according to the manufacturer's instructions. To each well of the ELISA plate were added $100 \mu \mathrm{l}$ of the patient serum (1:100 diluted), and the plate was incubated at $37^{\circ} \mathrm{C}$ for half an hour. The plate was then washed 3 times with washing buffer. $100 \mu \mathrm{l}$ of a peroxidase-conjugated goat anti-human IgG antibody was added, and the plate was incubated again at $37^{\circ} \mathrm{C}$ for half an hour. After that the plate was washed, tetramethyl benzidine (TMB) substrate was added to each well, and the plate was incubated for 10 minutes at $37^{\circ} \mathrm{C}$. The reaction was stopped by adding $50 \mu \mathrm{l}$ of $2 \mathrm{~m}$ sulfuric acid to each well. The optical density (O.D.) was measured at $450 \mathrm{~nm}$.

\section{Dipstick Dye Immunoassay (DDIA)}

The serum samples were also tested by the DDIA method [5], with DDIA kits purchased form Wuxi Saide Medical Technology Co. Ltd., P.R. China. The tests were performed according to the instructions supplied by the manufacturer. In brief, to each polyvinyl chloride (PVC) well a drop of blue colloidal dye-labeled soluble egg antigens (SEA) solution was added, followed by $20 \mu \mathrm{l}$ of serum. The content of the well was then mixed gently for one minute, and a dipstick was inserted into the well.
Ten minutes later, when the solution was absorbed completely, the result was read by eye. Positive samples had two blue bands on the control line and the test line of the dipstick, while a negative one only had one single blue band on the control line.

\section{ELISA antigen assay}

Two ELISA kits were used to detecting circulating antigens in all serum samples. One was purchased from Sichuan Maker Biotechnology Co. P.R. China (which was designed to detecting circulating $S$. japonicum SEA antigen in the serum of patients). The second one was a sandwich ELISA established by our laboratory using a combination of anti-S. japonicum SEA-IgY polyclonal antibodies and anti-S. japonicum SEA-IgM monoclonal antibodies. The specificity of the sandwich ELISA for detecting circulating S. japonicum SEA antigen in the serum of infected individuals has been established [44]. The steps involved in testing a sample with the two kits were basically the same as described for the ELISA antibody assay. The main difference was that each well of the commercial ELISA was loaded with $50 \mu \mathrm{l}$ serum directly, while the ELISA developed by our lab required $100 \mu \mathrm{l}$ serum solution in each well (1:5 diluted).

\section{Statistical analysis}

Groups were compared by the Chi-square test or Fisher's exact test as appropriate. Differences were considered significant when the P-value was less than 0.05 . 95\% confidence intervals (CIs) to the prevalence values of each method were also calculated.

\section{Results}

The sero-prevalence of Schistosoma japonicum according to different methods

Among the 1864 individual sera, 240 were antibody positive as tested with the IHA method in the field immediately after the serum samples were collected. This translates into an average antibody positive rate across the five villages of $12.7 \%$. The ELISA method gave the same results as the IHA but the number of positive samples according to the DDIA method was a little

Table 1 Prevalence of Schistosoma japonicum according to different diagnostic methods

\begin{tabular}{|c|c|c|c|c|c|c|c|c|c|c|c|c|}
\hline \multirow[t]{2}{*}{ Village } & \multirow[t]{2}{*}{ Total } & \multicolumn{2}{|c|}{ Kato-Katz method } & \multicolumn{5}{|c|}{ Immunodiagnostic antibody assay } & \multicolumn{3}{|c|}{ Immunodiagnostic antigen assay } & \multirow[b]{2}{*}{$\begin{array}{c}\text { Average (\%) } \\
{[95 \% \mathrm{Cl}]}\end{array}$} \\
\hline & & $\begin{array}{l}\text { Positive } \\
\text { (number) }\end{array}$ & $\begin{array}{c}\text { Positive (\%) } \\
{[95 \% \mathrm{Cl}]}\end{array}$ & $\mathrm{IHA}$ & ELISA & DDIA & $\begin{array}{c}\text { Average } \\
\text { (number) }\end{array}$ & $\begin{array}{c}\text { Average (\%) } \\
{[95 \% \mathrm{Cl}]}\end{array}$ & $\begin{array}{l}\text { ELISA } \\
\text { (COM) }\end{array}$ & $\begin{array}{c}\text { ELISA } \\
(\lg Y)\end{array}$ & $\begin{array}{c}\begin{array}{c}\text { Average } \\
\text { (number) }\end{array} \\
\end{array}$ & \\
\hline Village A & 544 & 1 & $0.2[0.03-0.33]$ & 30 & 30 & 29 & 29.7 & $5.5[3.58-7.42]$ & 15 & 14 & 14.5 & $2.7[1.34-4.06]$ \\
\hline Village B & 239 & 1 & $0.4[0.08-0.75]$ & 11 & 11 & 11 & 11 & $4.6[1.94-7.26]$ & 1 & 1 & 1 & $0.4[0.08-0.75]$ \\
\hline Village C & 311 & 7 & $2.3[0.63-4.0]$ & 44 & 44 & 44 & 44 & $14.1[10.23-17.97]$ & 18 & 15 & 16.5 & $5.3[2.81-7.79]$ \\
\hline Village D & 361 & 10 & $2.8[1.1-4.5]$ & 87 & 87 & 81 & 85 & $23.5[19.13-27.87]$ & 34 & 30 & 32 & 8.9 [5.96-11.84] \\
\hline Village $\mathrm{E}$ & 409 & 9 & $2.2[0.78-3.62]$ & 68 & 68 & 66 & 67.3 & 16.5 [12.90-20.10] & 19 & 21 & 20 & 4.9 [2.81-6.99] \\
\hline Total & 1864 & 28 & 1.5 [0.95-2.05] & 240 & 240 & 231 & 237 & $12.7[11.19-14.21]$ & 87 & 81 & 84 & $4.5[3.56-5.44]$ \\
\hline
\end{tabular}


Table 2 Key characteristics of six different diagnostic methods

\begin{tabular}{ccccccccc}
\hline Assay & $\begin{array}{c}\text { Tested } \\
\text { samples }\end{array}$ & $\begin{array}{c}\text { Positive } \\
\text { samples }\end{array}$ & $\begin{array}{c}\text { Adjusted prevalence } \\
\text { (\%) [95\% Cl] }\end{array}$ & $\begin{array}{c}\text { Detection } \\
\text { target }\end{array}$ & Solid phase & $\begin{array}{c}\text { Time required } \\
\text { per sample }\end{array}$ & $\begin{array}{c}\text { Volume } \\
\text { of sample }\end{array}$ & $\begin{array}{c}\text { Extra } \\
\text { supplies* }\end{array}$ \\
\hline IHA & 1864 & 240 & $12.9[11.38-14.42]$ & Anti-SEA antibody & Red blood cells from sheep & $40 \mathrm{~min}$ & $25 \mu \mathrm{ll}$ & Yes \\
ELISA & 1864 & 240 & $12.9[11.38-14.42]$ & Anti-SEA antibody & Microtitre plate & $90 \mathrm{~min}$ & $1 \mu \mathrm{\mu l}$ & Yes \\
DDIA & 1864 & 231 & $12.4[10.90-14.90]$ & Anti-SEA antibody & Nitrocellulose membrane & $15 \mathrm{~min}$ & $10 \mu \mathrm{ll}$ & $\mathrm{No}$ \\
ELISA (COM) & 1864 & 87 & $4.7[3.74-5.66]$ & Circulating antigen & Microtitre plate & $90 \mathrm{~min}$ & $50 \mu \mathrm{\mu l}$ & Yes \\
ELISA (IgY) & 1864 & 81 & $4.3[3.40-5.22]$ & Circulating antigen & Microtitre plate & $90 \mathrm{~min}$ & $20 \mu \mathrm{Hl}$ & Yes \\
Kato-Katz & 1864 & 28 & 1.5 & Egg & Plastic template & $40 \mathrm{~min}$ & $41.7 \mathrm{mg}$ & Yes \\
\hline
\end{tabular}

${ }^{*}$ Additional equipment required for all serological tests consisted of handheld micropipettes and micropipette tips.

smaller than with the two other methods. When tested for antigens produced by the parasite, average positive rates of respectively $4.7 \%$ (ELISA (COM)) and $4.3 \%$ (ELISA (IgY)) were recorded. Among the 240 fecal samples from IHA positive participants, S. japonicum eggs were detected in 28 with the Kato-Katz method. Thus, the average parasitological prevalence in the five villages was $1.50 \%$ (Table 1 ).

\section{Major features and statistical comparison of the six different diagnostic methods}

Major features of the diagnostic tests are listed in Table 2. The three immunodiagnostic antibody assays (IHA, DDIA and ELISA) were all developed in P.R. China and met the national criteria for field use. The antigen used for all tests was a crude soluble S. japonicum egg extract and the specimen tested in all kits was serum. However, the sample volume differed between assays: an ELISA test needs just $1 \mu \mathrm{l}$ serum whereas the IHA assay and the DDIA assay need $25 \mu \mathrm{l}$ and $10 \mu \mathrm{l}$, respectively. The two immunodiagnostic antigen assays were both ELISA tests. The Kato-Katz method was the only parasitological method we used in this study. Significant differences were observed between the prevalence according to the Kato-Katz method and all the five immunodiagnostic assays (Figure 1 and Table 3).

\section{Detection of antibodies or antigen in S. japonicum egg-positive patients}

The 28 S. japonicum egg-positive individuals include 7 (25\%) women and $21(75 \%)$ men. The median age was 54 years, with a range of 30 to 72 years. Twenty $(71.4 \%)$ of the egg positive individuals were farmers, and 8 (28.6\%) individuals had other occupations. The EPG values ranged between 8 and 736, with $10.7 \%$ having $\geq 100$ EPG, 21.4\% having 50-100 EPG and 67.9\% having $\leq 50$ EPG. No co-infection with other helminths was detected in the 28 samples. The rate of positive results for each immunological antibody and antigen test of the 28 parasitological positive samples is detailed in Table 4. The three antibody tests correctly diagnosed $100.0 \%$ of the egg-positive individuals while the two antigen tests detected 93.0\% (ELISA (COM)) and 86\% (ELISA (IgY)) of the cases. However, this difference was not statistically significant $(\mathrm{P}>0.05)$. The 4 false negative specimens were mostly from patients with EPG values of 24 or less.

\section{Discussion}

The prevention and control of schistosomiasis japonica in P.R. China still faces serious challenges, and accurate diagnosis is crucial for the effective control and surveillance of the disease. According to the latest national epidemiological sampling survey, the average prevalence was $5.1 \%$ in the areas where control of schistosomiasis

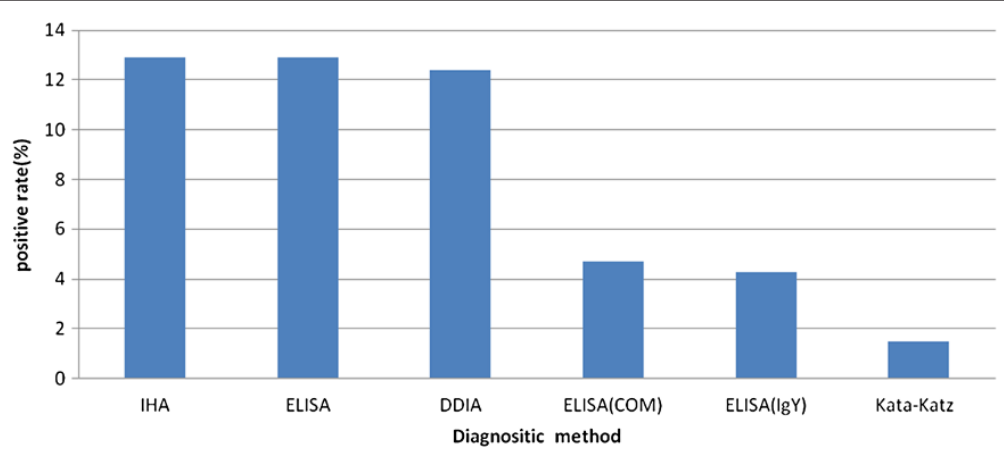

Figure $1 \mathrm{~S}$. Japonicum prevalence according to six different test systems. 
Table 3 Statistical comparison of the results from six different methods to diagnose S. japonicum infections (P values)

\begin{tabular}{|c|c|c|c|c|c|c|c|}
\hline \multirow[t]{2}{*}{ Type } & & \multicolumn{3}{|c|}{ Circulating antibody assays } & \multicolumn{2}{|c|}{ Circulating antigen assays } & \multirow{2}{*}{$\begin{array}{c}\text { Parasitological method } \\
\text { Kato-Katz }\end{array}$} \\
\hline & & IHA & ELISA & DDIA & ELISA-COM & ELISA-IgY & \\
\hline \multirow[t]{3}{*}{ Circulating antibody assays } & $\mathrm{IHA}$ & & & & & & \\
\hline & ELISA & 1 & & & & & \\
\hline & DDIA & $0.0495^{*}$ & $0.0495^{*}$ & & & & \\
\hline \multirow[t]{2}{*}{ Circulating antigen assays } & ELISA-COM & $<0.0001^{* *}$ & $<0.0001^{* *}$ & $<0.0001^{* *}$ & & & \\
\hline & ELISA-IgY & $<0.0001^{* *}$ & $<0.0001^{* *}$ & $<0.0001^{* *}$ & 0.0833 & & \\
\hline Parasitological method & Kato-Katz & $<0.0001^{* *}$ & $<0.0001^{* *}$ & $<0.0001^{* *}$ & $<0.0001^{* *}$ & $<0.0001^{* *}$ & \\
\hline
\end{tabular}

*indicates significant difference $(p<0.05)$; **indicates highly significant difference $(p<0.001)$.

transmission had not yet been achieved, and in all surveyed endemic areas the average prevalence was $2.5 \%$ [45]. To achieve the ultimate goal of elimination, a national program was established with the aim of decreasing the prevalence of schistosome infection in all endemic counties below 5\% in 2008 and 1\% in 2015 [46,47]. The study region in Jiangling county is a hyper-endemic area of $S$. japonicum in accordance with the current national prevalence classification. The five villages can be divided into two different levels, village $\mathrm{A}$ and $\mathrm{B}$ where the average prevalence is $0.3 \%$ according to the gold standard (KatoKatz method), much lower than in the villages C, D and E where the prevalence was $2.4 \%$.

Serological diagnosis of anti-schistosome antibodies has been widely used in endemic areas because it is more sensitive than parasitological diagnosis and antibodies are easier to detect than antigens [43]. In this study, we used three circulating antibody detection methods, IHA, ELISA and DDIA. They demonstrated a good ability to identify schistosomiasis patients, with positive rates in the range of $12.9 \%, 12.9 \%$ and $12.4 \%$. The IHA and ELISA gave the same results. The antibody ELISA can give quantitative results based on OD values, but the need for a $37^{\circ} \mathrm{C}$ incubator and a microplate reader to obtain results limits its use. IHA tests are the most widely used assays in P.R. China and only need an incubator. The DDIA method gave the lowest number of positive results but has its own advantages: the time required per sample of DDIA is only 15 min, no extra supplies are needed and it is suitable for large-scale screenings. Despite the advantages of these methods, detection of circulating antibodies also has its disadvantages as detecting antibodies cannot distinguish between current and past infections. Evaluating treatment outcomes is thus impossible, as antibodies are retained in the body for a number of years after treatment $[9,48]$.

Conversely, detection of parasite antigen may indicate the existence of active infection, and can greatly reduce the rate of false-positive results compared to antibody detection tests. This reduces costs of field investigations while improving accuracy of diagnosis. The reduced sample size required for surveillance and improved targeting of infected individuals with this method are particularly welcome as after years and years of praziquantel chemotherapy, treatment compliance in endemic areas is worsening $[49,50]$. In this study, two antigen detection methods had been evaluated. The prevalence according to the two methods were $4.3 \%$ (ELISA (IgY)) and $4.7 \%$ (ELISA (COM)). There were no significant differences between the two methods $(P=0.083)$. The average prevalence according to the two antigen-detecting methods was $4.5 \%$, higher than with the parasitological method (1.5\%), and lower than with the antibodydetecting methods (12.7\%). The reason probably is that the fraction of truly infected individuals that tested positive in stool examinations was very low [51,52], resulting in many false-negative diagnoses [53-55]. Antigen detection methods may more accurately reflect the existence of active infections in the population, and allow the evaluation of treatment outcomes. However, antigen detection ELISA methods are not a complete solution as we found that among the 28 serum samples from egg-positive individuals, antigens were detected only in 24 samples while 4 samples tested negative (these being subjects with EPG

Table 4 Detection of antibodies or antigen in S. japonicum egg-positive patients $(n=28)$

\begin{tabular}{cccccc}
\hline Assay & No. of positives & No. of false negatives & EPG* for misdiagnosed & Sensitivity (\%) & P value against Kato-Katz \\
\hline IHA & 28 & 0 & 0 & $100 \%$ & 1 \\
ELISA & 28 & 0 & 0 & $100 \%$ & 1 \\
DDIA & 28 & 0 & 0 & $100 \%$ & 1 \\
ELISA(COM) & 26 & 2 & 8,8 & $93 \%$ & 0.48 \\
ELISA(IgY) & 24 & 4 & $24,8,8,8$ & $86 \%$ & 0.13 \\
\hline
\end{tabular}

*EPG: egg per gram feces. 
counts of 24 or less). If we accept that stool examination is the "gold standard" for the detection of schistosomiasis and that all individuals with a positive stool examination finding were truly infected with $S$. japonicum, antigen detection would have a sensitivity of $89.3 \%$ (25/28). The following points are offered for consideration. 1. There is a problem with false-negative results in ELISA kits for antigen detection; 2. There is no linear relationship between the concentration of circulating antigens in the patient's body and the number of S. japonicum eggs in the patient's stools as the concentration of circulating antigens is influenced by many other factors, such as the health condition and immune status of the patient, or the formation of circulating immune complexes which are difficult to detect [56].

Both the immunodiagnostic antibody assays (IHA, ELISA and DDIA), and the immunodiagnostic antigen assays (ELISA (IgY) and ELISA (COM)) need collection of whole blood samples via venipuncture. This is a limitation because well trained personnel are required and the practice is not always widely accepted by the population. In recent years, based on the observation that parasite antigens may indicate the existence of an active infection, and its detection can greatly reduce the falsepositive rate of antibody detection tests, immunodiagnostic antigen assays (SEA, CCA and CAA) have been heralded as ideal diagnostic tests, and a number of circulating antigen assays have been developed to detect Schistosoma japonicum or Schistosoma mansoni infections [57-60]. A rapid diagnostic test has also been developed to detect circulating cathodic antigen (CCA) of Schistosoma mansoni in urine [61]. In our study we chose to only focus on schistosome egg antigen, and not CCA or CAA. Schistosomiasis japonica is different from the other three schistosome species in that in the chronic stage, patients may develop liver fibrosis, also called schistosome egg-induced fibrosis, indicating that eggs play an important role in the development of the pathology. So though CCA and CAA have the advantage of being antigens directly associated with adult worm feeding, SEA is expected to be more indicative of an active infection than CCA or CAA in the chronic and later stage. The sandwich ELISA developed in our laboratory using a combination of anti-S. japonicum SEA-IgY polyclonal antibodies and anti-S. japonicum SEA-IgM monoclonal antibodies (ELISA (IgY)) gave almost the same results as the ELISA (COM)) assay which is wildly used in P.R. China. In conclusion, we believe that immunodiagnostic techniques to detect circulating antigens have the potential to be deployed for schistosomiasis japonica screening in the endemic areas.

\section{Conclusions}

Our study confirmed that both circulating antibody and circulating antigen assays had acceptable performance characteristics. But significant differences were observed between the antigen and antibody assays ( $\mathrm{P}$ value $<0.0001)$. The sandwich ELISA developed in our laboratory for detecting circulating antigen gave great results in this study, so we believe immunodiagnostic techniques to detect circulating antigens have potential to be deployed for schistosomiasis japonica screening in the endemic areas.

\section{Competing interests}

The authors declare that they have no competing interests.

\section{Authors' contributions}

Conceived and designed the experiments: YCC, JFX, JXC. Performed the Experiments: YCC, JFX, JG, SHC, MXC, XMT, HL, LGT, LA, LLZ, YZ. Analyzed the data: YCC, JFX, LGT, PS. Wrote the paper: YCC, JFX, JXC, PS. All authors read and approved the final version of the manuscript.

\section{Acknowledgements}

We thank all staffs form the National Institute of Parasitic Diseases, Chinese Center for Disease Control and Prevention who were involved in this study.

\section{Funding}

Project support was provided by the National Key Technology R\&D Program (Grant No.2008BAI56B03) and the National S \& T Major Program (Grant No. 2012ZX10004-220 and 2008ZX10004-011).

\section{Author details}

${ }^{1}$ National Institute of Parasitic Diseases, Chinese Center for Disease Control and Prevention, Shanghai 200025, People's Republic of China. ${ }^{2}$ Key Laboratory of Parasite and Vector Biology, Ministry of Health, Shanghai 200025, People's Republic of China. 'WHO Collaborating Centre for Malaria, Schistosomiasis and Filariasis, Shanghai 200025, People's Republic of China. ${ }^{4}$ School of Medicine, Hubei University for Nationalities, Enshi, Hubei 445000, P.R. China. ${ }^{5}$ Department of Epidemiology and Public Health, Swiss Tropical and Public Health Institute, 4051 Basel, Switzerland. ' University of Basel, 4051 Basel, Switzerland.

Received: 25 September 2013 Accepted: 14 March 2014

Published: 31 March 2014

\section{References}

1. Hotez PJ, Kamath A: Neglected tropical diseases in sub-Saharan Africa: review of their prevalence, distribution, and disease burden. PLOS Negl Trop Dis 2009, 3:e412.

2. King $\mathrm{CH}$ : Parasites and poverty: the case of schistosomiasis. Acta Trop 2010, 113:95-104.

3. King CH: Toward the elimination of schistosomiasis. N Engl J Med 2009, 360:106-109.

4. Xu J, Feng T, Lin DD, Wang QZ, Tang L, Wu XH, Guo JG, Peeling R, Zhou $\mathrm{XN}$ : Performance of a dipstick dye immunoassay for rapid screening of Schistosoma japonicum infection in areas of low endemicity. Parasit Vectors 2011, 4:87.

5. Zhou YB, Liang S, Jiang QW: Factors impacting on progress towards elimination of transmission of schistosomiasis japonica in China. Parasit Vectors 2012, 5:275.

6. Wang LD, Guo JG, Wu XH, Chen HG, Wang TP, Zhu SP, Zhang ZH, Steinmann P, Yang GJ, Wang SP, Wu ZD, Wang LY, Hao Y, Bergquist R, Utzinger J, Zhou XN: China's new strategy to block Schistosoma japonicum transmission: experiences and impact beyond schistosomiasis. Trop Med Int Health 2009, 14:1475-1483.

7. Chen JH, Wang H, Chen JX, Bergquist R, Tanner M, Utzinger J, Zhou XN: Frontiers of parasitology research in the People's Republic of China: infection, diagnosis, protection and surveillance. Parasit Vectors 2012, 5:221.

8. Sun LP, Wang W, Liang YS, Tian ZX, Hong QB, Yang K, Yang GJ, Dai JR, Gao $Y$ : Effect of an integrated control strategy for schistosomiasis japonica in the lower reaches of the Yangtze River, China: an evaluation from 2005 to 2008. Parasit Vectors 2011, 4:243. 
9. Hamilton JV, Klinkert M, Doenhoff MJ: Diagnosis of schistosomiasis: antibody detection, with notes on parasitological and antigen detection methods. Parasitology 1998, 117(Suppl):S41-S57.

10. Zhu YC: Immunodiagnosis and its role in schistosomiasis control in China: a review. Acta Trop 2005, 96:130-136

11. Day JH, Grant AD, Doherty JF, Chiodini PL, Wright SG: Schistosomiasis in travellers returning from sub-Saharan Africa. BMJ 1996, 313:268-269.

12. Feldmeier $H$, Poggensee $\mathrm{G}$ : Diagnostic techniques in schistosomiasis control. A review. Acta Trop 1993, 52:205-220.

13. Yu JM, De Vlas SJ, Yuan HC, Gryseels B: Variations in fecal Schistosoma japonicum egg counts. Am J Trop Med Hyg 1998, 59:370-375.

14. Engels D, Sinzinkayo E, Gryseels B: Day-to-day egg count fluctuation in Schistosoma mansoni infection and its operational implications. Am J Trop Med Hyg 1996, 54:319-324.

15. Doenhoff MJ, Kusel JR, Coles GC, Cioli D: Resistance of Schistosoma mansoni to praziquantel: is there a problem? Trans $R$ Soc Trop Med Hyg 2002, 96:465-469.

16. Bonesso-Sabadini PI, de Souza Dias LC: Altered response of strain of Schistosoma mansoni to oxamniquine and praziquantel. Mem Inst Oswaldo Cruz 2002, 97:381-385

17. Stete K, Krauth SJ, Coulibaly JT, Knopp S, Hattendorf J, Müller I, Lohourignon LK, Kern WV, N'goran EK, Utzinger J: Dynamics of Schistosoma haematobium egg output and associated infection parameters following treatment with praziquantel in school-aged children. Parasit Vectors 2012, 5:298

18. Wu W, Huang Y: Application of praziquantel in schistosomiasis japonica control strategies in China. Parasitol Res 2013, 112:909-915.

19. Chen MG: Use of praziquantel for clinical treatment and morbidity control of schistosomiasis japonica in China: a review of 30 years' experience. Acta Trop 2005, 96:168-176.

20. Lin DD, Liu JX, Liu YM, Hu F, Zhang YY, Xu JM, Li JY, Ji MJ, Bergquist R, Wu GL, Wu HW: Routine Kato-Katz technique underestimates the prevalence of Schistosoma japonicum: a case study in an endemic area of the People's Republic of China. Parasitol Int 2008, 57:281-286.

21. Zhou XN, Bergquist R, Leonardo L, Yang GJ, Yang K, Sudomo M, Olveda R: Schistosomiasis japonica control and research needs. Adv Parasitol 2010, 72:145-178.

22. Seto EY, Remais JV, Carlton EJ, Wang S, Liang S, Brindley PJ, Qiu D, Spear RC, Wang LD, Wang TP, Chen HG, Dong XQ, Wang LY, Hao Y, Bergquist R, Zhou $\mathrm{XN}$ : Toward sustainable and comprehensive control of schistosomiasis in China: lessons from Sichuan. PLoS Negl Trop Dis 2011, 5:e1372.

23. Bergquist NR: Present aspects of immunodiagnosis of schistosomiasis. Mem Inst Oswaldo Cruz 1992, 87(suppl 4):29-38.

24. Goncalves MM, Barreto MG, Peralta RH, Gargioni C, Goncalves T, Igreja RP, Soares MS, Peralta JM: Immunoassays as an auxiliary tool for the serodiagnosis of Schistosoma mansoni infection in individuals with low intensity of egg elimination. Acta Trop 2006, 100:24-30.

25. Katz N, Chaves A, Pellegrino J: A simple device for quantitative stool thick-smear technique in schistosomiasis mansoni. Rev Inst Med Trop Sao Paulo 1972, 14:397-400.

26. Doenhoff MJ, Chiodini PL, Hamilton JV: Specific and sensitive diagnosis of schistosome infection: can it be done with antibodies? Trends Parasitol 2004, 20:35-39.

27. Duus LM, Christensen AV, Navntoft D, Tarp B, Nielsen HV, Petersen E: The Schistosoma-specific antibody response after treatment in non-immune travellers. Scand J Infect Dis 2009, 41:285-290.

28. Hillyer GV, Gómez de Rios I: The enzyme-linked immunosorbent assay (ELISA) for the immunodiagnosis of schistosomiasis. Am J Trop Med Hyg 1979, 28:237-241.

29. Tosswill JHC, Ridley DS: An evaluation of the ELISA for schistosomiasis in a hospital population. Trans R Soc Trop Med Hyg 1986, 80:435-438.

30. Zhou YB, Yang MX, Wang QZ, Zhao GM, Wei JG, Peng WX, Jiang QW: Field comparison of immunodiagnostic and parasitological techniques for the detection of schistosomiasis japonica in the People's Republic of China. Am J Trop Med Hyg 2007, 76:1138-1143.

31. Deelder AM, Klappe HTM, Van den Aardweg G, Van Meerbeke E: Schistosoma mansoni: demonstration of two circulating antigens in infected hamsters. Exp Parasitol 1976, 40:189-197.

32. Kahama Al, Kremsner PG, Van Dam GJ, Deelder AM: The dynamics of a soluble egg antigen of Schistosoma haematobium in relation to egg counts, circulating anodic and cathodic antigens and pathology markers before and after chemotherapy. Trans R Soc Trop Med Hyg 1998, 92:629-633.

33. Legesse M, Erko B: Field-based evaluation of a reagent strip test for diagnosis of Schistosoma mansoni by detecting circulating cathodic antigen in urine before and after chemotherapy. Trans $R$ Soc Trop Med Hyg 2007, 101:668-673.

34. Van Lieshout L, Polderman AM, Deelder AM: Immunodiagnosis of schistosomiasis by determination of the circulating antigens CAA and CCA, in particular in individuals with recent or light infections. Acta Trop 2000, 77:69-80.

35. Van Lieshout L, Polman K, Gryseels B, Deelder AM: Circulating anodic antigen levels in two areas endemic for schistosomiasis mansoni indicate differences in worm fecundity. Trans R Soc Trop Med Hyg 1998 92:115-119.

36. Van Lieshout L, Polderman AM, Visser LG, Verwey JJ, Deelder AM: Detection of the circulating antigens CAA and CCA in a group of Dutch travellers with acute schistosomiasis. Trop Med Int Health 1997 2:551-557.

37. Van Lieshout L, Polderman AM, De Vlas SJ, De Caluwé P, Krijger FW, Gryseels B, Deelder AM: Analysis of worm burden variation in human Schistosoma mansoni infections by determination of serum levels of circulating anodic antigen and circulating cathodic antigen. J Infect Dis 1995, 172:1336-1342.

38. Van Lieshout L, Gangaram Panday U, De Jonge N, Krijger FW, Oostburg BFJ, Polderman AM, Deelder AM: Immunodiagnosis of schistosomiasis mansoni in a low endemic area in Surinam by determination of the circulating antigens CAA and CCA. Acta Trop 1995, 59:19-29.

39. Polman K, Stelma FF, Gryseels B, Van Dam GJ, Talla I, Niang M, Van Lieshout L, Deelder AM: Epidemiologic application of circulating antigen detection in a recent Schistosoma mansoni focus in northern Senegal. Am J Trop Med Hyg 1995, 53:152-157

40. Fillié YE, Van Lieshout L, Kornelis D, Deelder AM: Evaluation of an ELISA for combined measurement of CAA and CCA in schistosomiasis mansoni. Acta Trop 1994, 57:279-287.

41. Berhe N, Medhin G, Erko B, Smith T, Gedamu S, Bereded D, Moore R, Habte E, Redda A, GebreMichael T, Gundersen SG: Variations in helminth faecal egg counts in Kato-Katz thick smears and their implications in assessing infection status with Schistosoma mansoni. Acta Trop 2004, 92:205-212.

42. Xu JF, Xu J, Li SZ, Jia TW, Huang XB, Zhang HM, Chen M, Yang GJ, Gao SJ, Wang QY: Transmission risks of schistosomiasis japonica: extraction from back-propagation artificial neural network and logistic regression model. PLoS Negl Trop Dis 2013, 7:e2123.

43. Xu J, Peeling RW, Chen JX, Wu XH, Wu ZD, Wang SP, Feng T, Chen SH, Li H, Guo JG, Zhou XN: Evaluation of immunoassays for the diagnosis of Schistosoma japonicum infection using archived sera. PLOS Negl Trop Dis 2011, 5:e949.

44. Cai YC, Guo J, Chen SH, Tian LG, Steinmann P, Chen MX, Li H, Ai L, Chen JX: Chicken egg yolk antibodies (IgY) for detecting circulating antigens of Schistosoma japonicum. Parasitol Int 2012, 61:385-390.

45. Zhou XN, Guo JG, Wu XH, Jiang QW, Zheng J, Dang H, Wang XH, Xu J, Zhu HQ, Wu GL, Li YS, XU XJ, Chen HG, Wang TP, Zhu YC, Qiu DC, Dong XQ, Zhao GM, Zhang SJ, Zhao NQ, Xia G, Wang LY, Zhang SQ, Lin DD, Chen MG, Hao Y: Epidemiology of schistosomiasis in the People's Republic of China, 2004. Emerg Infect Dis 2007, 13:1470-1476.

46. Wang L, Utzinger J, Zhou XN: Schistosomiasis control: experiences and lessons from China. Lancet 2008, 372:1793-1795.

47. Wang LD, Chen HG, Guo JG, Zeng XJ, Hong XL, Xiong JJ, Wu XH, Wang XH, Wang LY, Xia G, Hao Y, Chin DP, Zhou XN: A strategy to control transmission of Schistosoma japonicum in China. N Engl J Med 2009, 360:121-128.

48. Gentile R, Gon alves MML, Neto SFC, Costa MM, Peralta RHS, Peralta JM: Evaluation of immunological, parasitological and molecular methods for the diagnosis of Schistosoma mansoni infection before and after chemotherapy treatment with praziquantel in experimentally infected Nectomys squamipes. Vet Parasitol 2011, 180:243-249.

49. Cesari IM, Ballen DE, Mendoza L, Matos C: Detection of Schistosoma mansoni membrane antigens by immunoblot analysis of sera of patients from low-transmission areas. Clin Diagn Lab Immunol 2005, 12:280-286.

50. Stothard JR: Improving control of African schistosomiasis: towards effective use of rapid diagnostic tests within an appropriate disease surveillance model. Trans R Soc Trop Med Hyg 2009, 103:325-332. 
51. Knopp S, Rinaldi L, Khamis I, Stothard JR, Rollinson D, Maurelli MP, Steinmann P, Marti H, Cringoli G, Utzinger J: A single FLOTAC is more sensitive than triplicate Kato-Katz for the diagnosis of low-intensity soil-transmitted helminth infections. Trans R Soc Trop Med Hyg 2009, 103:347-354.

52. De Vlas SJ, Gryseels B: Underestimation of Schistosoma mansoni prevalences. Parasitol Today 1992, 8:274-277.

53. Barreto ML, Franca Silva JT, Mott KE, Lehman JS Jr: Stability of faecal egg excretion in Schistosoma mansoni infection. Trans R Soc Trop Med Hyg 1978, 72:181-187.

54. Teesdale CH, Fahringer K, Chitsulo L: Egg count variability and sensitivity of a thin smear technique for the diagnosis of Schistosoma mansoni. Trans R Soc Trop Med Hyg 1985, 79:369-373.

55. Kongs A, Marks G, Verle P, Van Der Stuyft P: The unreliability of the Kato-Katz technique limits its usefulness for evaluating $S$. mansoni infections. Trop Med Int Health 2001, 6:163-169.

56. Phillips TM, Draper CC: Circulating immune complexes in schistosomiasis due to Schistosoma mansoni. Br Med J 1975, 2:476-477.

57. Lu Y, Xu B, Ju C, Mo X, Chen S, Feng Z, Wang X, Hu W: Identification and profiling of circulating antigens by screening with the sera from schistosomiasis japonica patients. Parasit Vectors 2012, 5:115.

58. Midzi N, Butterworth AE, Mduluza T, Munyati S, Deelder AM, Van Dam GJ: Use of circulating cathodic antigen strips for the diagnosis of urinary schistosomiasis. Trans R Soc Trop Med Hyg 2009, 103:45-51.

59. Van Dam GJ, Wichers JH, Ferreira TMF, Ghati D, Van Amerongen A, Deelder AM: Diagnosis of schistosomiasis by reagent strip test for detection of circulating cathodic antigen. $J$ Clin Microbiol 2004 42:5458-5461.

60. Legesse M, Erko B: Field-based evaluation of a reagent strip test for diagnosis of schistosomiasis mansoni by detecting circulating cathodic antigen (CCA) in urine in low endemic area in Ethiopia. Parasite 2008, 15:151-155.

61. Coulibaly JT, Knopp S, N'Guessan NA, Silué KD, Fürst T, Lohourignon LK, Brou JK, N'Gbesso YK, Vounatsou P, N'Goran EK, Utzinger J: Accuracy of urine circulating cathodic antigen (CCA) test for Schistosoma mansoni diagnosis in different settings of Côte d'Ivoire. PLoS Negl Trop Dis 2011 5:e138.

doi:10.1186/1756-3305-7-138

Cite this article as: Cai et al:: Field comparison of circulating antibody assays versus circulating antigen assays for the detection of schistosomiasis japonica in endemic areas of China. Parasites \& Vectors 2014 7:138

\section{Submit your next manuscript to BioMed Central and take full advantage of:}

- Convenient online submission

- Thorough peer review

- No space constraints or color figure charges

- Immediate publication on acceptance

- Inclusion in PubMed, CAS, Scopus and Google Scholar

- Research which is freely available for redistribution 